\title{
STRATEGI PENGEMBANGAN USAHA KECIL MENENGAH SEKTOR INDUSTRI PENGOLAHAN KABUPATEN BEKASI
}

\author{
Oleh : \\ Hari Sulistiyo \\ Fakultas Ekonomi - Universitas Singaperbangsa Karawang \\ hari.sulistiyo@fe.unsika.ac.id \\ R. Aditya Kristamtomo Putra \\ raden.aditya@fe.unsika.ac.id \\ Fakultas Ekonomi - Universitas Singaperbangsa Karawang
}

\begin{tabular}{l}
\hline Article Info \\
\hline Article History: \\
Received 29 July - 2020 \\
Accepted 20 August - 2020 \\
Available Online \\
O7 Sept - 2020
\end{tabular}

Keyword :

SMEs, Location Quotient Analysis (LQ), Descriptive Analysis, and SWOT Analysis.

\begin{abstract}
The role of Micro, Small and Medium Enterprises or Small and Medium Enterprises (SMEs) in a country's economic growth is considered important. SMEs have a large and crucial contribution to the Indonesian economy. MSMEs have an important role in development and economic growth. The role of SME is not only felt in developing countries but also in developed countries. In developed and developing countries, MSME is very important, because it absorbs the most labor compared to large businesses. The contribution of MSMEs to the formation or growth of Gross Domestic Product (GDP) is greater than the contribution of large businesses. However, in reality the amount is inversely proportional to quality. Many MSME actors whose HR quality is still low, both in education and technology. The low quality of human resources has an impact on their productivity. This study aims to find out how the Development Strategy of Micro Small and Medium Enterprises in the Manufacturing Industry Sector in Bekasi District. The use of the Location Quotient (LQ) method is used to find out what business bases can be used by MSMEs based on $L Q$ analysis calculations. The use of TOWS analysts deepens the discussion of what and how MSME strategies compete. From the $L Q$ analysis calculation results it appears that Bekasi Regency, the processed industry business sector, is a leading sector with an $L Q$ index number > 1. As we know, Bekasi Regency's economic strength is indeed sourced from the industrial sector. Furthermore, the SME development strategy is based on the TOWS analysis, with the characters in each of the different MSMEs. The strategies used include: SO (Strength Opportunities), ST (Strength Threat) strategy, WO (Weakness Opportunites) strategy and WT (Weakness Threat) strategy.
\end{abstract}




\section{PENDAHULUAN}

Pembangunan nasional merupakan usaha peningkatan kualitas manusia dan masyarakat Indonesia yang dilakukan secara berkelanjutan, berlandaskan kemampuan nasional, dengan memanfaatkan kemajuan ilmu pengetahuan dan teknologi serta memperhatikan tantangan perkembangan global. Untuk itu pembangunan ekonomi rakyat seharusnya menjadi prioritas utama pembangunan ekonomi nasional, karena tujuan pembangunan ekonomi rakyat sesuai dengan amanat konstitusi yaitu: meningkatkan kesejahteraan dan keadilan sosial bagi seluruh rakyat Indonesia. Reformasi dalam sistem ekonomi nasional harus diarahkan kepada sistem ekonomi kerakyatan yang memberikan prioritas pembangunan ekonomi pada Koperasi dan Usaha Mikro, Kecil dan Menengah. Pada publish BPS.(2020) Luas wilayah Kabupaten Bekasi pada tahun 2019 sebesar 127.388 hektar $(1.273,88 \mathrm{~km} 2)$. Secara administrative terbagi menjadi 23 kecamatan dengan 7 kelurahan serta 180 desa. Kabupaten Bekasi merupakan wilayah yang cukup besar dengan berbagai potensi dan peranannya dalam andil perekonomian Jawa Barat maupun nasional. Secara geografis wilayah Kabupaten Bekasi merupakan jalur utama perekonomian memasuki gerbang ibukota Jakarta, dengan letak yang sangat strategis yaitu berbatasan langsung dengan Ibukota Negara sehingga berimplikasi pada pesatnya pembangunan serta adanya pertambahan penduduk yang cepat. Angka proyeksi penduduk Kabupaten Bekasi tahun 2019 sebanyak 3.763.886 jiwa. Pesatnya pertumbuhan penduduk tersebut sebagai akibat dari tingkat urbanisasi yang tinggi. Kabupaten Bekasi merupakan salah satu barometer perekonomian nasional khususnya sektor industri pengolahan, sehingga ada kecenderungan arus migrasi untuk mencari pekerjaan khususnya di daerah industri seperti Kecamatan Cikarang Pusat, Cikarang Utara, Cikarang Selatan, Cikarang Barat, Tambun Selatan serta Cibitung. Hal ini terlihat dengan tercirikannya Kabupaten Bekasi sebagai daerah industri besar berskala nasional/asing dengan kontribusi sektor ini terhadap total PDRB mencapai 77,79 persen, sehingga baik-buruknya perekonomian Kabupaten Bekasi juga memberikan sinyal terhadap baik buruknya perekonomian nasional.

Perkembangan perekonomian Kabupaten Bekasi, yang diukur dengan beberapa indikator ekonomi salah satunya adalah Produk
Domestik Regional Bruto (PDRB) Kabupaten Bekasi cukup memberikan harapan terhadap peluang berinvestasi maupun memberikan dampak nilai tambah ekonomi terhadap masyarakat. Ini tercermin dari laju pertumbuhan ekonomi Kabupaten Bekasi selama 5 tahun terakhir (2015-2019) memperlihatkan pertumbuhan diatas rata-rata nasional yaitu pertumbuhan rata-rata 5,04 persen pertahun. Namun, di Tahun 2019, laju pertumbuhan ekonomi Kabupaten Bekasi mengalami perlambatan yang sangat berarti, yaitu hanya 4,18 persen, jauh dibawah laju pertumbuhan ekonomi Jawa Barat dan Nasional.

Sebagai daerah sentra Kabupaten Bekasi yang menjadi tujuan para urban untuk mencari pekerjaan. Namun, harapan para pekerja untuk dapat terserap di sektor industri akan tergantung kemampuan dan keahlian dari para pekerja iu sendiri. Pada akhirnya, dengan kemampuan yang mereka miliki, mereka berusaha mempertahankan hidup melalui usaha UMKM. UMKM mempunyai peran penting di Bekasi dalam pembangunan ekonomi. Hal ini disebabkan, karena tingkat penyerapan tenaga kerjanya yang relatif tinggi (Munandar,2016) dan kebutuhan modal investasinya yang kecil, UMKM bisa dengan fleksibel menyesuaikan dan menjawab kondisi pasar yang terus berubah. Hal ini membuat UMKM tidak rentan terhadap berbagai perubahan eksternal. UMKM justru mampu dengan cepat menangkap berbagai peluang, misalnya untuk melakukan produksi yang bersifat substitusi impor dan meningkatkan pemenuhan kebutuhan dalam negeri. Karena itu, pengembangan UMKM dapat menunjang diversifikasi ekonomi dan percepatan perubahan struktural, yang merupakan prasyarat bagi pembangunan ekonomi jangka panjang yang stabil dan berkesinambungan.

Tambunan (2012) menyatakan masalah UMKM pada umumnya dapat dibedakan menajdi masalah internal dan eksternal, yaitu:

a) Rendahnya kualitas sumber daya manusia khususnya dalam manajemen, organisasi, teknologi, dan pemasaran;

b) Lemahnya kompetensi kewirausahaan;

c) Terbatasnya kapasitas umkm untuk mengakses permodalan, informasi teknologi dan pasar, serta faktor produksi lainnya.

Sementara itu, masalah eksternal yang dihadapi oleh UMKM di antaranya:

a) Besarnya biaya transaksi akibat kurang mendukungnya iklim usaha; 
b) Praktik usaha yang tidak sehat;

c) Keterbatasan informasi dan jaringan pendukung usaha.

d) Selain itu, umkm juga menghadapi tantangan terutama yang ditimbulkan oleh pesatnya perkembangan globalisasi ekonomi dan liberalisasi perdagangan bersamaan dengan cepatnya perkembangan teknologi.

Pada era perdagangan bebas, dua kondisi utama yang harus dipersiapkan oleh UMKM, yakni kondisi internal dan eksternal. Pada kondisi internal, yang harus dipenuhi adalah: kualitas sumber daya manusia khususnya dalam manajemen, organisasi, teknologi, dan pemasaran; kompetensi kewirausahaan; kapasitas UMKM untuk mengakses permodalan, informasi teknologi dan pasar, serta faktor produksi lainnya. Sedangkan pada kondisi eksternal, kondisi yang harus terpenuhi agar UMKM mampu berkembang dengan baik, antara lain: yang terkait dengan kebijakan pemerintah, aspek hukum, kondisi persaingan pasar, kondisi ekonomi-sosialkemasyarakatan, kondisi infrastruktur, tingkat pendidikan masyarakat, dan perubahan ekonomi global. Disamping itu, strategi pemberdayaan UMKM untuk dapat memasuki pasar global menjadi sangat penting bagi terjaminnya kelangsungan hidup UMKM.

Berdasarkan latar belakang tersebut perlu dilakukan kajian untuk mengetahui jenis UMKM yang potensial yang sesuai hasil yang diperoleh melalui perhitungan Location Quotient (LQ), maka kajian ini menitik beratkan pada : Bagaimana Strategi Pengembangan Usaha Mikro Kecil dan Menengah Sektor Industri Pengolahan Kabupaten Bekasi?

\section{KAJIAN PUSTAKA \\ PEGEMBANGAN HIPOTESIS}

DAN

\section{Analisis Location Quotient (LQ)}

Teknik ini digunakan untuk mengidentifikasi potensi internal yang dimiliki suatu daerah yaitu sektor-sektor mana yang merupakan sektor basis dan mana yang bukan sektor basis. Formulasi LQ secara matematis dapat

\begin{tabular}{ll} 
dituliskan & \multicolumn{1}{c}{ sebagai berikut. } \\
$L Q=\frac{S_{i} I S}{N_{i} I N}$ & \\
Keterangan: & \\
$\mathrm{LQ}=$ & Nilai Location Quotient \\
$\mathrm{Si}=$ & PDRB sektor I di Kota \\
& Tangerang \\
$\mathrm{S}=$ & PDRB total di Kota \\
& Tangerang \\
$\mathrm{Ni}=$ & PDRB sektor I di Banten \\
$\mathrm{N}=$ & PDRB total di Banten
\end{tabular}

\section{Analisis SWOT}

Analisis SWOT digunakan sebagai dasar penentuan strategi untuk mengetahui kekuatan dan kelemahan serta tantangan dan peluang yang akan dihadapi oleh UMKM. Analisis SWOT adalah analisis kondisi internal maupun eksternal suatu organisasi yang selanjutnya akan digunakan sebagai dasar untuk merancang strategi dan program kerja (Rangkuti, 1997). Analisis internal meliputi peniaian terhadap faktor kekuatan (Strength) dan kelemahan (Weakness). Sementara, analisis eksternal mencakup faktor peluang (Opportunity) dan tantangan (Threath).

\section{Analisis Deskriptif}

Analisis dalam penelitian ini dilakukan dengan pendekatan statistik deskriptif. Analisis ini memberikan gambaran pola- pola yang konsisten dalam data, sehingga hasilnya dapat dipelajari dan ditafsirkan secara singkat dan mendalam berdasarkan hasil analisis deskriptif (Kuncoro, 2003). Dalam analisis deskriptif dilakukan interprestasi atas data dan hubungan yang ada dalam penelitian tersebut. Di samping itu juga dilakukan komparasi antara hasil penelitian dengan hasil-hasil penelitian terkait dan dilakukan korelasi antara hasil- hasil penelitian tersebut dengan teori atau konsep yang relevan

\section{METODE PENELITIAN}

Dalam penelitian ini lokasi yang dijadikan lokus penelitian adalah Kabupaten Bekasi. Penelitian ini menggunakan data sekunder yang diperoleh dari BPS Kab.Bekasi, BPS Jawa Barat, RPJMD/RPJPD Kab. Bekasi, Data UMKM dari Departemen Koperasi, Bappeda Kab. Bekasi. 


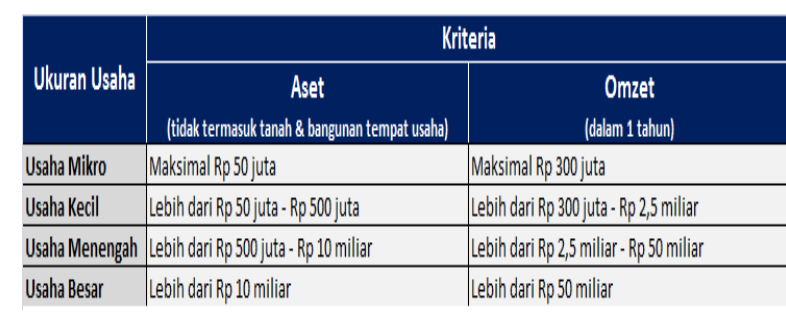

Sumber: UU No.20/2008 tentang Usaha Mikro,

Kecil, dan Menengah

Tujuan penelitian ini adalah untuk menjawab pertanyaan penelitian Bagaimana Strategi Pengembangan Usaha Kecil Menengah di Kabupaten Bekasi? Khususnya dalam pengembangan UMKM dalam sektor industry pengolahan. Data sekunder yang digunakan adalah PDRB Kab. Bekasi dan Provinsi Jawa Barat tahun 2015-2019. Tenik LQ menggunakan perbandingan data PDRB antara data kabupaten dan provinsi. . Untuk mengetahui komoditas potensial yang perlu dikembangkan dilakukan analisis Location Quentient (LQ). Langkah selanjutnya adalah dengan melakukan analisis deskriptif mengenai tingkat penyerapan tenaga kerja dan jumlah lowongan pekerjaan yang ada di Kab. Bekasi, serta penyerapan tenaga kerja oleh sektor UMKM. Dari hasil pengolahan ini akan terlihat seberapa besar pengaruh UMKM dalam perekonomian Kab. Bekasi.Kamudian hasil ini dikombinasikan dengan analisis SWOT untuk mendapatkan strategi apa yang tepat bagi pengembangan UMKM di Kab. Bekasi. Hasil dari dua analisis tersebut dihubungkan dengan kebijakan-kebijakan dan strategi untuk mengembangkan UMKM yang ada di Kab. Bekasi. Kebijakan dan strategi ini ini dalam bentuk program pemerintah melalui Departemen Koperasi dan instansi yang bersngkutan serta hasil dari nalisis SWOT. Dalam langkah ini, akan dievaluasi program yang diambil dalam usaha mengembangkan UMKM, sehingga diharapkan pemerintah mampu membuat suatu kebijakan yang mendukung kemajuan usaha UMKM.

\section{HASIL DAN PEMBAHASAN}

\section{Analisis LQ}

Penentuan sector sector ekonomi yang termasuk dalam sector basis (basic ekonomi) yang memiliki peluang ekspor, maupu sector ekonomi yang tidak termasuk sector basis (non basic sector), dapat menggunakan analisis Location Quentient (LQ). Ukuran penilaian menggunakan kriteria LQ>1,Berikut Tabel hasil perhitungan LQ Kab. Bekasi pada periode 2015-2019
Tabel 1. Hasil Analisis Indeks Location Quotient Kab. Bekasi 2015-2019

\begin{tabular}{|c|c|c|c|c|c|c|c|}
\hline \multicolumn{7}{|l|}{ retror } & \multirow{3}{*}{$\begin{array}{l}\text { LORAT } \\
\text { RATA }\end{array}$} \\
\hline KATEGORI & IRAAN & 2015 & 2016 & 20117 & 2018 & 20119 & \\
\hline 1 & & & & & & & \\
\hline $\mathrm{A}$ & 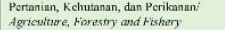 & 0.13 & 0.13 & 0.12 & 0.11 & 0.10 & 0.12 \\
\hline B & 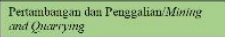 & 0.77 & 0.74 & 0.74 & 0.71 & 0.72 & 0.74 \\
\hline $\mathrm{c}$ & 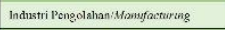 & 1.83 & 1.86 & 1.88 & 1.88 & 1.88 & 1.86 \\
\hline D & $\begin{array}{l}\text { Penngudaun listrik dan Gias':Lectricity } \\
\text { and Gias }\end{array}$ & 0.98 & 1.03 & 0.90 & 0.87 & 0.90 & 0.94 \\
\hline $\mathrm{t}$ & 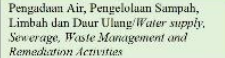 & 0.31 & 0.03 & 0.27 & 0.26 & 0.27 & 0.23 \\
\hline $\mathrm{F}$ & Kunatruksi Combraction & 0.77 & 0.79 & 0.78 & 0.77 & 0.78 & 0.78 \\
\hline (i & 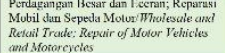 & 0.38 & 0.38 & 0.39 & 0.38 & 0.39 & 0.39 \\
\hline II & 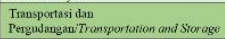 & 0.18 & 0.18 & 0.18 & 0.18 & 0.19 & 0.19 \\
\hline 1 & 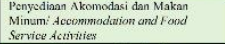 & 0.02 & 0.18 & 0.18 & 0.18 & 0.18 & 0.15 \\
\hline J & 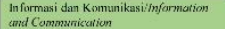 & 0.40 & 0.41 & 0.41 & 0.43 & 0.46 & 0.42 \\
\hline $\mathrm{K}$ & 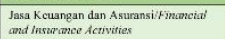 & 0.32 & 0.32 & 0.32 & 0.32 & 0.33 & 0.32 \\
\hline$\frac{1}{1}$ & 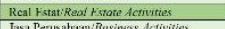 & $\frac{0.39}{0.92}$ & 0.04 & 0.04 & $\frac{0.42}{0.03}$ & 0.44 & 0.27 \\
\hline 0 & 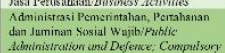 & 0.28 & 0.28 & 0.26 & 0.25 & 0.26 & 0.27 \\
\hline$p$ & 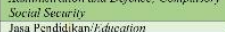 & 0131 & 0,32 & 0.31 & 0.30 & 0.29 & 0,31 \\
\hline Q & 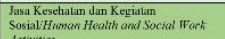 & 0.30 & 0.00 & 0.03 & 0.03 & 0.30 & 0.13 \\
\hline$\overline{R . S T . T U}$ & 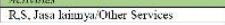 & 0.30 & 0.29 & 0.29 & 0.29 & 0.29 & 0.29 \\
\hline
\end{tabular}

Sumber: Data diolah

Berdasarkan Tabel diatas diperoleh gambaran bahwa di Kab. Bekasi hanya industry pengolahan / manufacturing yang memiliki angka indeks 1,86 dengan kata lain angka indeks LQ>1. Hal ini sesuai dengan karakteristik kab. Bekasi yang kekuatan ekonominya bersumber pada sektor industri. Kondisi ini menimbulkan pertanyaan lanjutan, bagaimana strategi pengembangan UMKM yang berada pada kondisi ini.

Industri pengolahan adalah kegiatan ekonomi yang mengolah bahan mentah, bahan baku, bahan setengah jadi, dan/atau barang jadi menjadi barang nilai yang lebih tinggi untuk penggunaannya, termasuk kegiatan rancang bangun dan perekayasaan industri.

Industri pengolahan adalah suatu kegiatan ekonomi yang melakukan kegiatan mengubah suatu barang dasar secara mekanis, kimia atau dengan tangan sehingga menjadi barang jadi, dan atau barang yang kurang nilainya menjadi barang yang lebih tinggi nilainya, dan sifatnya menjadi lebih dekat kepada pemakai akhir, termasuk jasa industri dan pekerjaan perakitan (assembling).

Berdasarkan data BPS jumlah tenaga kerja, industri pengolahan biasanya dikelompokkan menjadi:

1. Industri besar, jumlah tenaga kerja 100 orang atau lebih;

2. Industri sedang atau menengah, jumlah tenaga kerja 20 sampai 99 orang,;

3. Industri kecil, jumlah tenaga kerja 5 sampai 19 orang, dan;

4. Industri mikro atau rumah tangga, jumlah tenaga kerja 1 sampai 4 orang.

Di samping industri berdasarkan jumlah tenaga kerja, Industri juga dapat diklasifikasikan menjadi: 
1. Industri kimia dasar seperti industri semen, obat-obatan, kertas, dan pupuk.

2. Industri mesin dan logam dasar seperti industri pesawat terbang, kendaraan bermotor dan tekstil.

3. Industri kecil seperti industri roti, makanan ringan, es, dan minyak goreng curah.

4. Aneka industri seperti industri pakaian, makanan dan minuman.

(LPPI dan BI.2015)

Industri rumah tangga ini biasanya memiliki ciri-ciri sebagai berikut :

1. Memiliki modal yang sangat terbatas;

2. Tenaga kerja berasal dari anggota keluarga dan atau masyarakat sekitar;

3. Pemilik atau pengelola industri biasanya kepala rumah tangga itu sendiri atau anggota keluarganya;

Beberapa contoh usaha yang termasuk dalam industri rumah tangga ini adalah industri anyaman, industri kerajinan, industri tempe/tahu, industry makanan ringan dan minuman, suvenir, pakaian, peralatan rumah, dan industri bordir.

\section{Potensi Bisnis Sektor Industri Pengolahan}

Pertumbuhan industri pengolahan ini diperkirakan akan tetap signifikan karena ditopang oleh pasar dalam negeri yang besar dan potensial. Pelaku industri pengolahan nasional akan bisa memproduksi barang-barang bernilai tambah tinggi yang berdaya saing jauh lebih banyak dan diminati konsumen di dalam negeri maupun luar negeri.

\section{Hal-hal yang Harus Diperhatikan Pada} Bisnis Sektor Industri Pengolahan

Aspek kritis dalam bisnis sektor industri pengolahan, antara lain meliputi:

a. Lokasi usaha dan perizinan.

b. Apakah perusahaan anggota asosiasi.

c. Apakah perusahaan memiliki fasilitas pengolah limbah yang baik dan memenuhi standard yang ditetapkan oleh pemerintah (Sertifikat Amdal).

d. Apakah produk yang dihasilkan sudah terdaftar pada instansi yang terkait.

e. Apakah perusahaan beroperasi berdasarkan order dari perusahaan lain baik di dalam negeri maupun di luar negeri.

f. Status kepemilikan, teknologi dan kapasitas mesin dikaitkan dengan rencana produksi.

g. Jaminan ketersediaan energi (khususnya listrik).

h. Tenaga ahli yang dimiliki antara lain design, finishing dan mesin. i. Jumlah, kualitas dan kontinuitas tenaga kerja, apakah sesuai dengan peraturan pemerintah dan bagaimana hubungan industri yang ada selama ini.

j. Apakah perusahaan berorientasi ekspor, nasional/lokal atau kombinasi keduanya, jika perusahaan berorientasi ekspor harus diteliti apakah perusahaan memiliki kuota yang cukup dibandingkan dengan kapasitas dan rencana produksi.

k. Perusahaan lain yang memiliki produk sejenis. (Dpmptsp Kota Bogor.2017)

\section{Rantai Nilai bisnis Sektor Industri Pengolahan}

Rantai nilai bisnis sektor industri pengolahan dimulai dari adanya input supply yang diproses menjadi produksi bahan baku setengah jadi lalu finishing serta diperdagangkan dalam distribusi hasil yang pada akhirnya untuk industri konsumsi. Input supply berupa bahan baku, bahan pendukung dan bahan packing yang diperoleh dari pemasok (supplier), baik diperoleh langsung dari pemasok maupun melalui saluran distribusi.

Kemudian masuk ke proses produksi mulai dari produksi setengah jadi, barang jadi, dan pengemasan. Setelah itu mulai dipasarkan baik secara langsung maupun melalui saluran pemasaran kepada pembeli. Berikut gambaran Rantai Nilai Bisnis Industri Pengolahan

Gambar: Rantai Nilai Bisnis Industri

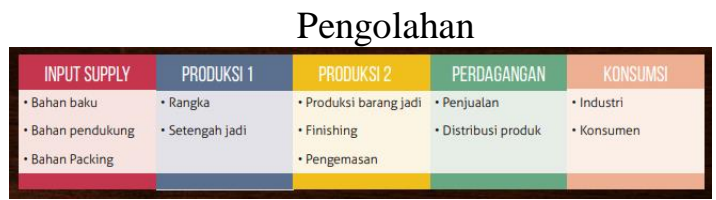

Sumber: Dpmptsp Kota Bogor.2017

\section{Profil Finansial Usaha Sektor Industri Pengolahan}

Profil Finansial dalam bisnis Industri pengolahan yang perlu diketahui antara lain aset, perputaran usaha, arus kas, struktur biaya, dan pendapatan usaha.

a. Aset

Aset adalah kekayaan yang menjadi bagian penting bagi bisnis industri pengolahan. Pengelolaan asset yang terbagi menjadi dua jenis yakni lancar dan asset tidak lancer. Untuk industry pengolahan mengelola asset tidak lancar merupakan hal paling penting bagi kelangsungan usahanya, disamping asset tidak lancer yang akan sangat tergantung pada besar dan kapasitas usahanya.

b. Perputaran Usaha 
Perputaran usaha akan tergantung dari jenis usaha yang dijalani. Perputaran industri usaha tempe, konveksi, sepatu akan tergantung berapa proses dari masingmasing produk, disamping tingkat teknologi yang dimiliki oleh masingmasing industry usaha.

c. Arus Kas

Pada gambar di atas, Nampak indsutri usaha pengolahan memiliki pola arus kas yang spesifik. Siklus pengolahan berawal dari input suplly yang berasal dari pembelian, baik berupa bahan baku, bahan pendukung maupun bahan packing. Proses ini kemudian dilanjutkan ke proses produksi, melakukan pemasaran dan pada kahirnya bermuara di penjualan. Arus Kas masuk dan keluar perlu diperhitungkan bagi kelanjutan usaha UMKM

d. Struktur Biaya dan Pendapatan Usaha Pada sector industry pengolahan struktur biaya tergantung dari jenis usaha dan kompleksitas proses produk olahan. Biaya pada umumnya meliputi biaya investasi dan biaya modal kerja. Adapun biaya investasi dapat berupa biaya sewa, biaya pembelian mesin dan alat-alat produksi. Sedang untuk operasional perusahaan dicukupi dengan biaya modal kerja. Pada indsutri pengolahan, seluruh pendapatan diperoleh melalui penjualan.

\section{Analisis SWOT}

Analisis SWOT adalah alat yang dipakai untuk menyusun faktor-faktor strategis internal dan eksternal, yaitu (Strength, Weakness, Opportunity dan Threat) dari faktor-faktor tersebut sehingga dapat diperoleh beberapa alternatif strategi yang berpengaruh untuk pembangunan daerah.

\begin{tabular}{|c|c|c|}
\hline $\begin{array}{c}\text { EKSTERNAL } \\
\text { INTERNAL }\end{array}$ & $\begin{array}{c}\text { OPPORTUNITY } \\
(\mathrm{O})\end{array}$ & $\begin{array}{c}\text { TREATHS } \\
(\mathrm{T})\end{array}$ \\
\hline $\begin{array}{c}\text { STREANGTH } \\
(\mathrm{S})\end{array}$ & $\begin{array}{c}\text { Comparative } \\
\text { Advantage } \\
\text { (SO) }\end{array}$ & $\begin{array}{c}\text { Mobilization } \\
\text { (ST) }\end{array}$ \\
\hline $\begin{array}{c}\text { WEAKNESS } \\
(\mathrm{W})\end{array}$ & $\begin{array}{c}\text { Divestment/Invest } \\
\text { ment } \\
(\mathrm{WO})\end{array}$ & $\begin{array}{c}\text { Damage } \\
\text { Control } \\
(\mathrm{WT})\end{array}$ \\
\hline
\end{tabular}

Sumber: Kearns (1992)

Peluang dan ancaman adalah bagian dari lingkungan eksternal - ini mencakup faktorfaktor yang memengaruhi tujuan atau proyek dari luar perusahaan. Ini dapat mencakup ekonomi, teknologi, peraturan dan perundangundangan, perubahan sosiokultural dan pergeseran dalam kompetisi.

Peluang adalah faktor di luar organisasi yang dapat dimanfaatkan oleh bisnis untuk mencapai tujuan bisnis dan memajukan bisnis. Ancaman termasuk apa pun di lingkungan eksternal yang dapat menyebabkan masalah bagi suatu proyek atau yang menimbulkan ancaman di masa depan bagi keberhasilan organisasi.

Kekuatan dan kelemahan adalah faktor internal yang bergantung pada tujuan, proyek atau inisiatif yang dianalisis. Karena subyektif terhadap tujuan yang dipilih, apa yang dianggap sebagai kekuatan untuk satu tujuan atau proyek mungkin menjadi kelemahan bagi yang lain.

Kekuatan ada di dalam kendali organisasi dan kategori ini mencakup semua yang dilakukan bisnis dengan benar ketika mencoba mencapai tujuan, inisiatif, proyek, atau tujuan tertentu. Apa pun yang memberi keuntungan bagi organisasi atau yang membantu proses dan proyek berjalan dengan lancar atau membantu organisasi mencapai tujuan bisnis akan termasuk dalam kategori ini.

Kelemahan juga ada dalam kendali organisasi, tetapi kategorinya mencakup segala sesuatu yang membuat bisnis tidak berada di jalurnya untuk mencapai tujuan dan sasaran bisnis atau proyek. Ini adalah hal-hal yang perlu diperbaiki atau diubah untuk mencapai kesuksesan.

Dari matrik SWOT diatas, dapat dibagi menjadi 4 sel, dengan masing-masing sel mempunyai ciri karakteristik masing-masing. Sel tersebut adalah:

(SO) untuk mengembangkan strategi 'maximaxi' - strategi dengan potensi keberhasilan terbesar. Misalnya, kekuatan seperti pengakuan merek yang tinggi atau loyalitas pelanggan dapat digabungkan dengan peluang untuk meluncurkan produk atau layanan baru. . Berdasarkan hasil kajian, strategi SO yang dirumuskan adalah sebagai berikut: menjaga dan meningkatkan kualitas produk, peningkatan sistem manajemen kualitas ke arah sertifikasi penjaminan kualitas (ISO), peningkatan kemitraan dengan industri-industri besar, melakukan Research dan Development dalam rangka pengembangan produk

Strategi ST adalah strategi yang menggunakan semua kekuatan untuk menghindari dari semua ancaman. Berdasarkan hasil kajian, strategi ST yang dirumuskan adalah sebagai berikut: meningkatkan kualitas produk, peningkatan sistem manajemen kualitas ke arah sertifikasi penjaminan kualitas (ISO), optimalisasi penggunaan teknologi produksi, peningkataan kerja sama dengan supplier bahan baku, dan diversifikasi produk.

Di antaranya, strategi mini-maxi (WO) dan maxi-mini (ST) dirancang untuk memperkuat kelemahan, memanfaatkan peluang, dan meminimalkan ancaman dengan memanfaatkan 
kekuatan. strategi mini-maxi strategy (WO) adalah bahwa suatu organisasi mungkin telah mengidentifikasi peluang untuk melakukan outsourcing beberapa aspek operasi bisnisnya, mengatasi kelemahan kurangnya keterampilan khusus dalam organisasi. Berdasarkan hasil kajian, strategi WO yang dirumuskan adalah sebagai berikut: peningkatan sistem manajemen kualitas ke arah sertifikasi penjaminan kualitas (ISO), peningkatan kompetensi karyawan, peningkatan tingkat pendidikan karyawan, peningkatan kesadaran terhadap pentingnya kualitas produk dan proses.

Strategi WT adalah strategi yang menekan semua kelemahan dan mencegah semua ancaman. Di sisi lain, ia menyoroti kerentanan organisasi terhadap ancaman berdasarkan kelemahannya dan memfasilitasi pengembangan strategi yang meminimalkan ini dan menghindari ancaman (WT) - strategi 'mini-mini'. Sebagai contoh, strategi seperti itu dapat mencakup pengembangan aliansi strategis atau strategi yang lebih drastis adalah penarikan dari pasar tertentu secara keseluruhan. Berdasarkan hasil kajian, strategi WT yang dirumuskan adalah sebagai berikut: peningkatan sistem manajemen kualitas ke arah sertifikasi penjaminan kualitas (ISO), peningkatan kesadaran terhadap pentingnya kualitas produk dan proses, dan Peningkataan kerja sama dengan supplier bahan baku

\section{Permasalahan UMKM pada Sektor Industri Pengolahan}

Beberapa hal yang menjadi penghambat pertumbuhan UMKM Indonesia dikelompokan ke dalam dua bagian, yaitu faktor internal dan faktor eksternal. Berdasarkan hal-hal tersebut, ada beberapa hal yang dapat dilakukan pemerintah untuk memperbaiki kinerja UMKM Indonesia, yang akan dibahas lebih detail pada bagian ini.

Faktor Internal (Produktivitas dan Inovasi) Keahlian manajerial. Sudah banyak penelitian yang membuktikan bahwa ada keterkaitan antara keahlian manajerial dengan daya survive Bagi UMKM. Keterkaitan keahlian yang rendah antara kebutuhan (demand) tenaga kerja UMKM dan lulusan (supply) Sekolah Menengah Kejuruan juga masih lemah. Hal itu banyak dikeluhkan oleh UMKM yang membutuhkan keahlian khusus untuk menjalankan usahanya. Kemampuan manajerial ini meliputi pengetahuan tentang entrepreneurship, pencatatan laporan keuangan, dan kemampuan berbahasa Inggris dapat menjadi prioritas dalam pengembangan UMKM. Pada kenyataannya dalam program tersebut karena berdasarkan haskondisi sekarang ditemukan bahwa banyak UMKM yang belum memiliki kemampuan dasar itu.

Banyak UMKM belum melek teknologi. Kementerian Koperasi dan UKM RI menyebut hingga 2018 Indonesia memiliki 64,1 juta pelaku usaha industri usaha mikro, kecil, dan menengah saat ini. Dari jumlah tersebut, baru 20 persen $(12,82$ juta) yang melek digital. Artinya masih ada 51,28 juta UMKM belum melek digital. Melihat fakta tersebut, penyedia sistem kasir digital, melalui program A Cup of Moka ingin membuat lebih banyak UMKM melek digital. (Viva.co.id di akses 14 Juli 2020). Balai Latihan Kerja Daerah (BLKD) tampaknya harus menyesuaikan kurikulum dengan kemajuan teknologi yang sudah dalam genggaman. Bagi UMKM penggunaan e commerce saat ini, merupakan alternative yang memberi peluang besar bagi pengembangan usaha. Sejogjanya pemeringtah mampu memfasilitasi pertemuan antara pemilik website e commerce dan UMKM.

\section{Pengetahuan Standarisasi dan Sertifikasi UMKM.}

UMKM harus memiliki pengetahuan tentang standarisasi dan sertifikasi usaha yang dijalankan. Hal ini penting, dalam rangka memasuki pasar ekspor. Pengetahuan tentang standar di negara yang dituju serta biaya pengurusan standar dan sertifikasi relatif mahal apabila ditanggung oleh usaha mikro dan kecil secara sendiri-sendiri dan biaya itu bersifat sunk cost sehingga apabila pemerintah dapat memfasilitasi UMKKM maka akan menurunkan biaya transaksi UMKM dan meningkatkan probabilitias perusahaan untuk melakukan ekspor

\section{Faktor Eksternal \\ Pemberian akses dan fasilitas khusus bagi UMKM.}

Untuk pengurusan perizinan di seluruh Badan Pelayanan Terpadu Satu Pintu di seluruh Indonesia perlu diinisiasi oleh pemerintah. Namun, fasilitas tersebut perlu diikuti oleh kebijakan lain, seperti kemudahan dan insentif pajak agar UMKM terdorong untuk menjadi badan usaha formal. Dalam mengatasi hal itu, pemerintah perlu melakukan terobosan seperti pembebasan terhadap pajak penghasilan $(\mathrm{PPh})$ badan selama awal usaha. 


\section{Akses Permodalan}

Merujuk data Bank Indonesia dan Otoritas Jasa Keuangan (OJK), sebanyak $70 \%$ dari total hampir 60 juta unit Usaha Mikro, Kecil dan Menengah (UMKM) di Indonesia belum mendapatkan akses pembiayaan dari perbankan.( finance.detik.com). Meski menurut paparan LPPI dan BI (2017), terdapat kenaikan jumlah kredit yang dikucurkan oleh perbankan selama periode 2011-2014, namun disinyalir penyeluran ini lebih banyak diperuntukkan bagi UMKM korporasi.

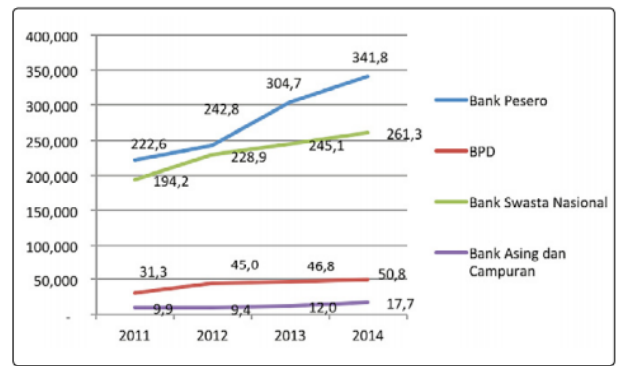

Sumber: LPPI dan BI

Gambar: Penyaluran Kredit UMKM oleh Bank Umum Periode 2011-2014

Dari data tersebut kita bisa melihat, perhatian perbankan terhadap UMKM semakin baik tiap tahunnya. Namun demikian, perbaikan harus terus menerus menjadi perhatian. Tidak hanya dari sisi kuantitas nilai kredit yang harus ditingkatkan, namun dari sisi kualitas pun perlu diperhatikan. Karena harus diakui, dari seluruh bank yang menyalurkan kredit, tidak semuanya memiliki pengalaman dan kompetensi yang memadai mengenai UMKM. Ada beberapa bank selama ini hanya fokus kepada penyaluran kredit korporasi. (LPPI dan BI,2017)

\section{Akses Pasar}

Akses pasar dalam jangka pendek bisa dilakukan dengan cara memprioritaskan produk lokal dalam pengadaan barang dan jasa pemerintah pusat hingga daerah. Saat ini, berbagai produk lokal bersaing dengan barang impor meski untuk kepentingan pemerintah. Kemampuan UMKM, selama ini tampaknya masih terbentur pada akses pasar terhadap produk yang dimilikinya.

\section{Infrastruktur}

Perbaikan infrastruktur yang sedang dilakukan pemerintah sangat ditunggu-tunggu dalam mengatasi bottleneck pertumbuhan ekonomi Indonesia. Pentingnya infrastruktur bagi UMKM pertama, untuk memberikan efisiensi dan efektivitas dalam berproduksi maupun memasarkan hasil produksinya. Kedua, mempercepat dan memperlancar penyediaan kebutuhan barang dan jasa bagi masyarakat dengan biaya yang lebih mudah dan murah.

\section{Rekomendasi Strategi Pengembangan UMKM}

Rekomendasi Strategi Pengembangan UMKM Dari berbagai konsep mengenai pemberdayaan masyarakat di bidang ekonomi, berikut beberapa pilihan strategi yang dilakukan dalam pemberdayaan UMKM, yaitu :

a. Kemudahan dalam Akses Permodalan

Kadin mendorong pemerintah untuk memberikan kemudahan dalam aspek per-modalan. Salah satu permasalahan yang dihadapi UKM adalah aspek permodalan. Yang perlu dicermati dalam usaha pemberdayaan UMKM melalui aspek permodalan ini adalah (1) bagaimana agar pemberian bantu-an modal ini tidak menimbulkan ketergantungan; (2) bagaima-na pemecahan aspek modal ini dilakukan melalui penciptaan sistem yang kondusif baru usaha mikro, usaha kecil, dan usaha menengah untuk mendapatkan akses di lembaga keuangan; (3) bagaimana agar skema penggunaan atau kebijakan peng-alokasian modal ini tidak terjebak pada perekonomian subsistem. Oleh karena itu, ke depan diperlukan adanya perbaikan dalam aspek permodalan, yang meliputi adanya bantuan permodalan dari pemerintah pusat dan daerah, serta kemudahan dalam birokrasi untuk pengurusan permodalan bagi UMKM. Di sisi lain, pemerintah juga harus bekerja sama dengan pihak swasta untuk medorong permodalan dalam industri UMKM, seperti pada bank-bank yang memberikan kredit mikro un-tuk UMKM serta kemudahan birokrasi dengan tingkat bunga yang rendah.

b. Bantuan Pembangunan Prasarana

Usaha mendorong produktivitas dan mendorong tumbuhnya usaha, tidak akan memiliki arti penting bagi masyarakat, kalau hasil produksinya tidak dapat dipasarkan, atau kalaupun dapat dijual tetapi dengan harga yang amat rendah. Oleh sebab, itu komponen penting dalam usaha pemberdayaan UMKM adalah pembangunan prasarana produksi dan pemasaran.

Pembentukkan klaster industri spesifik untuk UMKM secara signifikan dapat memperbaiki daya saing dan meningkatkan pertumbuhan UMKM. Infrastruktur tersebut juga dapat meningkatkan peran UMKM dalam GVC melalui keterkaitan UMKM dengan perusahaan besar. Infrastruktur fisik dan fasilitas yang terintegrasi untuk investasi, perdagangan, dan proses manufaktur dapat menarik perusahaan besar. Sementara itu, 
fasilitas kemudahan one-stop services bagi UMKM memberikan insentif untuk menempati area tersebut. Integrasi tersebut secara tidak langsung dapat menjadi pendorong untuk memperbaiki kualitas produk dan kapasitas sumber daya manusia UMKM. Pengembangan infrastruktur nonfisik pada klaster tersebut juga perlu dikembangkan oleh pemerintah. Fasilitasi dialog dan komunikasi di dalam klaster, antara perusahaan besar dan UMKM merupakan faktor penting lainnya untuk meningkatkan efisiensi dan menyelaraskan kualitas dan standar produk UMKM yang dibutuhkan oleh perusahaan besar.

c. Pengembangan Skala Usaha

Peningkatan skala usaha melalui pengelompokan atau pengorganisasian ekonomi yang diarahkan untuk memudahkan diperolehnya akses modal ke lembaga keuangan yang telah ada, dan untuk membangun skala usaha yang ekonomis. Aspek kelembagaan yang lain adalah dalam hal kemitraan antarskala usaha dan jenis usaha, pasar barang, dan pasar input produksi. Aspek kelembaga-an ini penting untuk ditangani dalam rangka penguatan dan pemberdayaan ekonomi masyarakat.

d. Pengembangan Jaringan Usaha, Pemasaran dan Kemitraan Usaha.

Upaya mengembangkan jaringan usaha ini dapat dilakukan dengan berbagai macam pola jaringan misalnya dalam bentuk jaringan sub kontrak maupun pengembangan kluster. Dalam hal fasilitasi promosi ke pasar internasional, pemerintah juga perlu lebih meningkatkan peran perwakilan Indonesia di luar negeri sebagai market intelligent untuk mendapatkan informasi terkait pasar potensial (potensi demand, hambatan perdagangan, termasuk standar dan sertifikasi yang diperlukan, serta prosedur untuk masuk ke negara tersebut). Di samping itu, kerja sama yang baik dengan kementerian teknis diperlukan untuk matchmaking informasi dari market intelligent mengenai pasar potensial dengan kemampuan produsen untuk memenuhi pasar tersebut, termasuk fasilitasi untuk mendapatkan sertifikasi dan pengurusan standar sehingga dapat diterima di pasar tujuan.

Pemerintah perlu mengunakan metode-metode baru yang inovatif untuk membantu UMKM mendapatkan pasar sehingga dengan anggaran yang sama akan lebih banyak UMKM yang dapat difasilitasi. Misalnya, bersinergi dengan pemerintah daerah (cost-sharing) serta menggiatkan e-catalogue serta promosi online lainnya.

Dalam aspek pemasaran, pemerintah juga perlu melakukan perbaikan-perbaikan melalui strategi dan upaya-upaya seperti berikut:

1) Melakukan penetrasi pasar bagi produk UMKM yang sekarang (existing product) terhadap pasar yang sudah dimasuki (existing market). Strategi ini cocok untuk dilak-sanakan dalam pemasaran produk UMKM dalam negeri.

2) Memperluas pasar produk UKM. Selama ini wujud upa-yanya adalah melalui program pameran internasional dan misi dagang serta pertemuan bilateral.

3) Mengembangkan produk UMKM. Program ini dilaksana-kan melalui modifikasi atau pembuatan produk baru pada pasar yang ada saat ini.

4) Diversifikasi. Program ini dimaksudkan untuk mencari pasar baru untuk produk UMKM yang juga baru.

e. Pengembangan Sumber Daya Manusia Dalam rangka memberdayagunakan UMKM dalam menghadapi serbuan produk impor dan dalam rangka kemampuan menembus pasar ekspor, maka pemerintah perlu meningkatkan kemapuan sumberdaya manusia dari pelaku UMKM. Peningkatan kemampuan di bidang manajerial, entrepreneurship haus dilakukan dengan berbagai cara baik pelatihan, On the job training, magang, seminar dan lokakarya, memfasilitasi pertemuan dengan pelaku UMKM yang telah lebih dahulu berkembang. Hal ini dilakukan dalam rangka peningkatan kualitas sumberdaya manusia dari pelaku UMKM. Upaya lain pengembangan SDM di sektor UMKM ini melalui usaha pendampingan. Pendampingan UMKM memang perlu dan penting. Tugas utama pendamping ini adalah memfasilitasi proses belajar atau re-fleksi dan menjadi mediator untuk penguatan kemitraan, balk antara usaha mikro, usaha kecil, maupun usaha menengah dengan usaha besar. Yang perlu dipikirkan bersama adalah siapa yang paling efektif menjadi pendamping masyarakat.

f. Peningkatan Akses Teknologi

Penguasaan teknologi meru-pakan salah satu faktor penting bagi pengembangan UsahaKecil Menengah.Di negara-negara maju, keberhasilan usaha kecil menengah ditentukan oleh penguasaan teknologi. Stra-tegi yang perlu dilakukan Kadin dalam peningkatan akses tek-nologi bagi pengembangan usaha mikro dan kecil atau me-nengah adalah mendorong pemerintah untuk memfasilitasi dan 
memotivasi berbagai lembaga penelitian teknologi yang lebih berorientasi untuk peningkatan teknologi sesuai kebu-tuhan UMKM, pengembangan pusat inovasi desain sesuai dengan kebutuhan pasar, pengembangan pusat penyuluhan dan difusi teknologi yang lebih tersebar ke lokasi-lokasi Usaha Mikro dan Kecil Menengah, dan peningkatan kerja sama anta-ra asosiasi-asosiasi UMKM dengan perguruan tinggi atau pu-sat-pusat penelitian untuk pengembangan teknologi UMKM.

g. Mewujudkan iklim bisnis yang lebih kondusif.

Persoalan yang selama ini terjadi iklim bisnis kurang kondusif dalam menunjang perkembangan usaha seperti terlihat dengan masih rendahnya pelayanan publik, kurangnya kepastian hukum dan berbagai peraturan daerah yang tidak pro bisnis merupakan bukti adanya iklim yang kurang kondusif. Oleh karena perbaikan iklim bisnis yang lebih kondusif dengan melakukan reformasi dan deregulasi perijinan bagi UMKM merupakan salah satu strategi yang tepat untuk mengembangkan UMKM. Dalam hal ini perlu ada upaya untuk memfasilitasi terselenggaranaya lingkungan usaha yang efisien secara ekonomi, sehat dalam persaingan dan non diskriminatif bagi keberlangsungan dan peningkatan kinerja UMKM. Selain itu perlu ada tindakan untuk melakukan penghapusan berbagai pungutan yang tidak tepat, keterpaduan kebijakan lintas sektoral, serta pengawasan dan pembelaan terhadap praktek-praktek persaingan usahah yang tidak sehat dan didukung penyempurnaan perundang-undangan serta pengembangan kelembagaan.

\section{KESIMPULAN}

Berdasarkan pada hasil pembahasan, maka dalam penelitian ini dapat ditarik kesimpulan sebagai berikut:

a. Berdasarkan hasil dari indeks Location Quentient (LQ), Kab. Bekasi sesuai karakter daerahnya, sector leading nya adalah sektor industri pengolahan dengan nilai indeks LQ $>1,86$

b. Beberapa pilihan strategi yang dilakukan dalam pemberdayaan UMKM, yaitu: Kemudahan dalam Akses Permodalan,Bantuan Pembangunan Prasarana, Pengembangan Skala Usaha, Pengembangan Jaringan Usaha, Pemasaran dan Kemitraan Usaha (melalui kegiatan: penetrasi pasar bagi produk UMKM,memperluas pasar produk UMKM, mengembangkan produk UMKM, Diversifikasi), Pengembangan Sumber Daya
Manusia, Peningkatan Akses Teknologi, Mewujudkan iklim bisnis yang lebih kondusif.

\section{DAFTAR PUSTAKA}

BPS. Bekasi Dalam Angka 2020. Diakses tgl 6 Juli 2020

https://bekasikab.bps.go.id/publication/202 0/04/27/a89af3319bbfa820b6dc8c2f/kabup aten-bekasi-dalam-angka-2020.html

BPS.https://www.bps.go.id/subject/9/industribesar-dan-sedang.html diakses tgl 14 Juli 2020

Amruloh, D. A. G. (2016). Kontruksi Hubungan Orientasi Wirausaha dengan Kinerja USAha (Studi Kasus pada UMKM Keramik Plered Purwakarta). Eqien: Jurnal Ekonomi dan Bisnis, 3(1), 23-29.

Dinas Penanaman Modal Dan Pelayanan Terpadu Satu Pintu (DPMPTSP) Kota Bogor.2017. Profil UMKM Unggulan Kota Bogor

Amruloh, D. A. G. (2012). Karakteristik Usaha dan Jiwa Wirausaha Terhadap Kinerja Usaha pada Usaha Mikro dan Kecil (UMK) Keramik Plered Purwakarta. Eqien: Jurnal Ekonomi dan Bisnis, 1(2), 41-56.

finance.detik.com/berita-ekonomi-bisnis/d4636059/akses-modal-dan-bahan-bakumasih-jadi-tantangan-umkm-ri. Di akses pada tanggal 14 Juli 2020

https://www.viva.co.id/berita/bisnis/1160138-5128-juta-umkm-di-indonesia-belum-melekdigital

Kearns, Kevin P. 1992. From Comparative Advantage to Damage Control.Clarifying Strategic Issues Using SWOT Analysis. Jossey Bass: Non Profit Management and Leadership, Vol 3, No.1, Fall 1992.

Kementerian UMKM. Statistik Usaha Mikro, Kecil dan Menengah Tahun 2010 - 2011. diakses dari www.depkop.go.id pada tanggal 24 Juni 2015.

LPPI dan BI.2015. Profil Bisnis Usaha Mikro, Kecil Dan Menengah (UMKM)

Munandar,A.2016. The Strategy Development And Competitive Advantages Of Micro Small Medium Entreprise Business Institution Toward Regional Development. Jurnal AdBispreneur Vol. 1, No. 2, Agustus 2016

Tambunan, Tulus T.H. 2012. Usaha Kecil dan Menengah di Indonesia: Beberapa isu-isu Penting. Jakarta: Penerbit Salemba Empat.

UU No.20/2008 tentang Usaha Mikro, Kecil, dan Menengah 